\title{
A PATCHWORK FAMILY: THE STRUGGLE FOR SURVIVAL IN PÖLSLER'S AUSTRIAN MOVIE DIE WAND
}

\section{Eckhard Rölz ${ }^{1 *}$}

*1 Department of Modern Languages and Global Studies South Dakota State University Brookings, South Dakota, USA

\section{*Corresponding Author: -}

\begin{abstract}
: -
The movie Die Wand (2013) was hugely successful in the German-speaking world and once dubbed, also in other countries. It is often described as a film depicting a woman living in utter isolation cut off from any social contact. I, however, argue that the protagonist, though she is without any human contact, creates a family-like order with the animals that have flocked to her. She is the dominant mother figure who takes care of her "children" and defends them when needed.
\end{abstract}

Keywords: - Austrian Film, Die Wand, Martina Gedeck, Marlen Haushofer, Film Awards 
The Wall [Die Wand] was Austria's contender for the 2014 Oscars. Though it was not considered as a finalist by the jury, it nevertheless became a hit in German speaking countries. The movie is based on the 1963 very successful novel Die Wand by Austrian author Marlen Haushofer (1920-1970). For the longest time, this novel was considered to be unverfilmbar, which means impossible to turn into a movie. ${ }^{1}$ However, in 2010 and 2011, Julian Pösler did the impossible, by turning the book into a successful movie. It was nominated for a number of awards and won the Berlin International Film Festival in 2012, the German Film Awards in 2013, and the Romy Gala in Austria also in 2013. Martina Gedeck of The Lives of Others fame plays the main, and almost only, human part in the film.

Though the book was well received and was popular between its publication and the release of the movie, I will only concentrate on the film. It is, however, important to remark, that reading the novel helps one better understand the movie as it explains many details the movie leaves out. As is typical in a book, the characters are considerably better developed and explained. In contrast, the movie leaves a lot of questions unanswered, making it more intriguing, interesting, and thought-provoking than the novel. It leaves the viewer longing for a catharsis and one wonders, after the credits have rolled, how the story might continue, as it abruptly ends without any indication of a happy end or any kind of end in sight. This unresolved ending and the unanswered questions cause those viewers, who watch the lengthy movie all the way to the end, to think about what might come next or how they would resolve the situation. It seems though that many viewers give up before the movie ends and many consider it an awfully boring film, mainly because of its omissions, a lack of a happy ending, and the slow pace and lack of action. Ulrich Greiner of Die Zeit, a German Newspaper writes: "Every attempt to figure out what the movie is telling us fails because it is utterly boring. It is a slow-moving depressing movie which leaves many questions open." The subtitle of the article is "Die Wand is very ambitious and very boring." 2 Boyd van Hoeij of Variety remarks that the constant voiceover turns the film into "a well-illustrated audiobook" in which "images and voiceover never quite fuse into a single whole." ${ }^{3}$ Neil Young of The Hollywood Reporter calls the cinematography "stunningly beautiful" but says that the characterization of the woman is lacking in back story, and the climax's "tonal shift is unsatisfyingly awkward."

Others are more positive: Gary Goldstein of the Los Angeles Times labels it "a remarkably involving film" that is "far more transfixing than it may sound." Neil Genzlinger of The New York Times calls it "a one-woman study of physical and mental survival" with a convincing performance by Gedeck. ${ }^{6}$ The Guardian writes: "It's hard to believe a film this minimal - part sci-fi parable, part feminist Robinson Crusoe - could contain so much."

Needless to say, Die Wand is a very unconventional movie, especially at a time when action and computer generated images seem to dominate the movie scene. The pace is slow, there is little action, but it is full of the protagonist's thoughts and reflections. The movie starts with three people, a couple, a younger woman with an older man and their dog Luchs, who are accompanied by the unnamed female protagonist who is also the voice-over narrator. They are travelling through to the beautiful Austrian mountains in an expensive Mercedes convertible. Their destination is a very nice two-story well equipped hunting lodge in the woods. Upon arrival, the couple decides to walk back to the village to eat or have a beer but the protagonist decides to stay behind. Surprisingly, their dog Luchs refuses to follow them to the village and chooses to stay with this woman at the lodge. The hours go by and she eventually retires when it gets dark.

The next morning, the woman finds herself alone with the dog and we learn that the couple never returned. Worried about their hosts, the woman leaves with the dog to head for the village and search for them. She is ill equipped for life in the Austrian mountains as she is wearing high heels on a rocky dirt road. As they are walking, Luchs runs ahead and we suddenly hear a yelping sound as if the dog was hurt. His mouth is bleeding and we soon learn what had caused this injury. As the woman is taking a step forward she walks into an invisible wall that blocks the road; a seemingly endless wall separates her and the dog from the other side of the valley.

In an attempt to find out what had happened, she looks for other people. The only other person she can see through the wall is a man who seems to be frozen still - however, the water is still running and the leaves are moving. It seems to her that a tragedy had killed all humans on the other side of the wall. She is entirely alone, protected and trapped by the invisible wall in equal measure.

Apparently, her logic and rational thinking prevail because she seems to come to terms with her fate fairly quickly. Her reaction during her first encounter with the wall is absolutely astonishing. There are rocks to throw, fists for pounding, but she quickly resigns herself to the fact that there is a wall. No attempt to tunnel under, no screams of desperation, no prayers, just resignation. Later she makes the only convincing attempt by driving the couple's Mercedes into the invisible wall which is stronger than this finely engineered German automobile.

Lucky for her, the cabin or hunting lodge is well equipped with lots of supplies, clothes that fit her, weapons, ammunition and lamp fuel. She also has a pencil and some paper - the back of an old calendar and old business letters. Not only is there a friendly mutt, an abundance of wild game, numerous guns, there are also amazing panoramic views for when the loneliness gets especially crushing. ${ }^{8}$ This city woman quickly adjusts to her new situation and becomes quite proficient in hunting, gathering edible fruits and greens, gardening, and surviving in the wild. Because the area in which she is trapped is fairly wide, and filled with fruits and animals of the surrounding forest along with her garden and supplies, she learns to live off her supplies.

Luchs, the dog, seems to take care of himself throughout the movie, but soon a number of animals appear that are dependent on our protagonist: First there is a white cat and later a pregnant cow. Though this typical city woman who initially walks and stumbles on a dirt road in high heels, who is well dressed and who seems utterly unfit for life in the Austrian mountains, is ill prepared for living off the land, she quickly adapts and becomes a good marksman, butcher, gardener, and dairy farmer. It is absolutely astonishing and quite unbelievable that this woman picks up a shotgun, kills a deer, field-dresses it and lives off the meat for a while without having refrigeration or any other way of preserving the 
meat. She is able to eat well, though little is known as to what she eats or how she prepares it. The cabin might have been well stocked but eventually lamp oil, food, fuel, ammunition, surely would have to run out after three years.

One day, to her great astonishment, a pregnant cow suddenly appears near the cabin. The cow seems to seek the closeness of people and is not shy at all. Luckily, the cabin has a stable and that is where the cow resides from then on. The heroine is able to milk her without problems. On the downside, she now has to provide for the cow as well, which is not difficult in the summer because of the luscious mountain meadows, but she has to make hay for the winter. She has a few difficulties using a scythe but a few blisters later she does very well. The question where she acquired all her skills remains unanswered.

The transformation is astonishing as she quickly and forcefully develops her primeval survival instincts. She is now exposed to the rules of nature; therefore, she gradually turns into an avid hunter and farmer, but not without a great deal of guilt, doubt, and loneliness. Perhaps the most devastating enemy in her new habitat is the immense silence and lack of human contact that coerce her to think about death.

In her loneness, the woman quickly develops a strong bond with Luchs, the dog, her only companion initially. After she is joined by the cat and the cow, they all reside together in a family-like situation in that lodge and keep each other company. Though it is true that they live in utter isolation, away from human contact and the rest of the world, our protagonist actually does not live alone. Martin Schwickert of Die Zeit wonders: "What remains of a human being who lives in total and utter isolation?" ${ }^{9}$ but that is not exactly the case. Her life is not far removed from a real family dynamic. Though detached from society, she establishes a new family-like domestic community in the wilderness. Not unlike how female prison inmates frequently arrange themselves in groups resembling a family, with a mother, often an older inmate, a father figure and children, this protagonist surrounds herself with companions that bring to mind a family.

Luchs, the dog is the first creature with whom she develops a relationship. It seems this faithful and forgiving male canine takes on the role of male partner. He protects her on their long hunts in the mountains, warns her of danger, is ever vigilant, and never lets her down. He has a tender heart and she can cry on his shoulder; but he also shows his teeth when danger appears. He sleeps next to her bed and is always there like a good husband would be. After two years she remarks: "That summer I quite forgot that Luchs was a dog and I was a human being. I knew it but it had lost any distinctive meaning." They develop a deep bond that lasts until Luch's death - which leaves her forlorn and confused. In spite of the fact that she is without human contact, she still experiences the bitter and the sweet, the ups and downs of life with her canine companion.

Though this woman has no children (a fact I know from the book) she is involved in the birthing process and in the raising of young ones all the same. First the cat gives birth to a litter but her involvement is very limited. Later the milk-giving pregnant cow delivers a healthy steer. Surprisingly, this city-woman knows exactly what to do to help this poor laboring cow give birth. Like a true experienced farmer she reaches in and pulls out that helpless calf. She toils greatly to give life to this new creature. She sweats, pulls and pushes, breathes heavily, and labors just like a birthing mother. In the end, she is exhausted, covered in blood and amniotic fluid, but is elated at the sight of the newborn calf. Her family has grown and she mothers them all.

It seems Luchs, the dog, takes care of himself but caring for these "children" is not easy. All these mouths have to be fed, including her own. She makes hay and stores it for the winter. She always has food for the cats and she even adopts a wild white crow. She feels sorry for this bird because he is shunned by his kind for the odd white color. Herself being an outsider, she can sympathize and so she feeds this bird daily.

As she is caring for her family, during her second summer, and while strolling through the beautiful Austrian woods she remarks: "I am not sure that my new self is not gradually getting absorbed into a greater whole. The transformation was starting." Surrounded by her family, sitting in a meadow, the cows grazing, Luchs by her side, she muses:

"It was almost impossible, in the buzzing stillness of the meadow, to remain a single separate self. A small, blind, independent life that didn't want to integrate into the greater community. Once my major source of pride was to lead just such a life. But up here it has struck me suddenly as pathetic and absurd. An overinflated nothing."

The once proud single successful modern city woman is changing and taking on family responsibilities and seeing herself as part of a greater whole, part of a family, a cohesive group and she is the sole provider for them.

The close relationship she has developed with her family becomes even more obvious when, after 2 years, a complete stranger appears. Out of nowhere, this man attacks with a big ax the precious little steer she helped birth. Most probably being in the same predicament as our heroine, he is undoubtedly elated at the sight of fresh meat, succulent steaks, and protein. As he is brutally chopping away at this steer, the woman reaches for her large caliber rifle and ruthlessly shoots him in the back.

The only living human she has seen in years and she is only focused on protecting her steer. So she takes drastic measures to save her beloved baby - but it is too late. When all is said and done, she carelessly drags the man's body by the feet across the field and rolls him over a cliff; and in stark contrast, she buries the remains of her beloved partner, her dog, who was also killed in the attack, in a deep grave. She mourns the loss as if she had lost two members of her family, two loved ones.

Though the protagonist is alone in the wilderness, cut off from society and human contact, she is absolutely not devoid of a family relationship. I propose that this family setting, focusing on caring for the animals and the pampering them as a good mother would her children, is what is keeping her sane, in addition to - by her own admission-writing her diary and recording her story. It is the closeness of Luchs, the dog and his ability to protect her that gives her the courage to live through the long, dark and scary nights, and to hunt in unknown forests for wild animals. It is the closeness to the cow and especially the calf that she helped bring into this world that helps her feel compassion, love, and charity. She gives up of herself, selflessly sacrificing to help these creatures survive. It is hard work keeping this family alive in the winter and it 
would be much easier for her to eat the livestock and only have to provide for herself. She however chooses the harder path, the path of more work but of love and charity. Most mothers dedicate a good portion of their lives to raising children, to give the children the best life possible. In the same way, the heroine adds worry for food and much work to her life to sustain and raise these "kids."

When watching this movie for the first time, one might be confused, stunned, fascinated, and bored at the same time. Confused, because the action jumps between earlier diary entries and now, and one can only tell the difference by the protagonist's haircut. Stunned, because the scenery is absolutely breathtaking and the cinematography is exquisite. Especially the winter scenes are incredibly beautiful. It is fascinating that a movie with so little action would even be produced these days. But one might also be bored because there are long drawn-out scenes where nothing much happens. It was a strange experience watching it for the first time; but this is one of these rare movies one should watch at least a second time because it becomes more fascinating every time one watches it.

\section{Endnotes and References:}

[1].Schwickert, Martin. "Gefangen in sich selbst." Zeit Online 11 October 2012: Web

[2].Greiner, Ulrich. "Zurück zur Natur." Die Zeit Online 11 Oct. 2012. Web

[3].van Hoeij, Boyd. "Review: 'The Wall."” Variety 18 Feb. 2012. Web

[4].Young, Neil. "The Wall: Berlin Film Review." The Hollywood Reporter 12 Feb. 2012. Web

[5].Goldstein, Gary. "Movie review: 'The Wall' makes isolation work." Los Angeles Times 13 June 2013. Web

[6].Genzlinger, Neil. "Trapped by an Invisible Force: 'The Wall,' Directed by Julian Pölsler." The New York Times 30 May 2013. Web

[7].Brooks, Xan. "The Wall-review." the guardian US edition 4 July 2013. Web

[8].Shoard, Catherine. "The Wall-review." the guardian US edition 6 July 2013. Web

[9].Schwickert, Martin. " Gefangen in sich selbst." Zeit Online 11 Oct. 2012. Web 